\title{
Vietnamese Perception Verbs - The Transfer of Their Cognitive Metaphors into English
}

\author{
Phuong Nguyen Hoang \\ Faculty of Vietnamese Studies, University of Social Sciences and Humanities, Vietnam National University, Hochiminh City, Vietnam
}

\section{Email address:}

nguyenhoangphuong@hcmussh.edu.vn, ling.dr.phuong@gmail.com

\section{To cite this article:}

Phuong Nguyen Hoang. Vietnamese Perception Verbs - The Transfer of Their Cognitive Metaphors into English. International Journal of Applied Linguistics and Translation. Vol. 4, No. 3, 2018, pp. 52-57. doi: 10.11648/j.ijalt.20180403.12

Received: September 8, 2018; Accepted: October 23, 2018; Published: November 16, 2018

\begin{abstract}
Fillmore stated that frame semantics offers a particular way of looking at word meanings, as well as a way of characterizing principles for creating new words and phrases, for adding new meanings to words, and for assembling the meanings of elements in a text into the total meaning of the text. [9, p.111] Besides, the semantics of Vietnamese perception verbs is very diverse, subtle, and complicated. Therefore, this article researches the cognitive metaphor semantics (meanings) of Vietnamese perception verbs and their semantic cognition transferred from Vietnamese into English. The researcher inspected and collected 3,946 sentences with perception verbs as research data from two sets of English-Vietnamese, Vietnamese-English bilingual novels: The adventures of Sherlock Holmes, Arthur Conan Doyle (English version and Vietnamese version), and Love after war, Wayne Karlin, Ho Anh Thai (edited) (Vietnamese version and English version). Then, cases of specific semantic cognition transferred from Vietnamese into English were tracked down by using statistical analysis method. Simultaneously, the linguistic methods, such as descriptive, analysis, and contrastive methods have been used to analyze and investigate in order to find out the basic ways these verbs can convey cognitive metaphor meanings. There are totally 6 modes of the cognitive metaphors of the perception verbs. Those cognitive metaphors are formed due to the dominance of the cognitive object, the dominance of the cognitive perceiver, being in the same cognition phase, cognitive spaces switching, cognitive results conversion and perception organs conversion. This research results can help learners, language users, translators and interpreters of Vietnamese and English work effectively and comprehensively in their bilingual interactions.
\end{abstract}

Keywords: Perception Verbs, Cognitive Metaphor, Cognitive Semantics, Semantic Cognition Transferred

\section{Introduction}

Metaphor is a cognitive phenomenon. [8, p.14] Metaphor helps humans to try to understand new problems in terms of existing cognitive resources. [13, p.325] Metaphor is a major and indispensable part of our ordinary, conventional way of conceptualizing the world, and that our everyday behavior reflects our metaphorical understanding of experience. [10, p.186] The widespread use of metaphorical language in our everyday lives has given rise to the idea that we do not only talk metaphorically much of the time, but that we may also think metaphorically much of the time. [5, p.68] And metaphors provide rich evidence about the ways in which some aspects of our lived experience are associated with others, for reasons that reflect basic aspects of perception, thought, and possibly neurological organization. [11, p.188]
In metaphor, the structure of a given domain (called the "source" domain) is mapped onto a different one (the "target" domain), which as a result is structured and understood in terms of the first one. [14, p.15] Besides, cognitive semantics sees linguistic meaning as a manifestation of conceptual structure: the nature and organization of mental representation in all its richness and diversity. [7, p.156] Verbalizations of non-verbal or conceptual metaphors may affect their possible interpretation. [12, p.10] In Vietnamese language, the semantics of the perception verbs is very interesting and deserves deep study and investigation. For instance, in Vietnamese, the verb thấy (see) can be used to express the information from all of the senses, not just the visual. The verb nghe (hear) also has a variety of meanings, which is only inferior to the verb thấy. Therefore, this article's aim is to research and study the cognitive metaphor 
semantics of Vietnamese perception verbs as well as their semantic cognition transfer between Vietnamese and English.

From the survey of the two sets of English-Vietnamese, Vietnamese-English bilingual novels: The adventures of Sherlock Holmes and Love after war, the researcher collected 1950 units with Vietnamese perception verbs (nhin, nghe, ngưi, nếm, sò and thấy) and 1996 units with English perception verbs (look, see, listen, hear, smell, taste, touch, feel). After having carefully processed, analyzed, and researched, the research data revealed that 6 reasons for the existence of cognitive metaphor meanings for those perception verbs. At the same time, the research has also tracked down all the possible semantic cognition transfers between Vietnamese and English.

\section{The Cognitive Metaphor Mechanism}

Basing the analysis of communicative interactions on mental states means, first and foremost, examining individual motivations, beliefs, goals, desires, and intentions. The next step in the analysis is to examine how these states are expressed. The definition of communication as a process implies that communicating linguistically or extralinguistically will involve two different ways of processing data. The same input may be analyzed from both a linguistic and an extralinguistic standpoint, and except in special cases, it will be processed in two parallel ways. [4, p. 1-2] Metaphor, understood traditionally, is an action of meaning transferring based on the similarity of objects in color, shape, nature of movement, etc. According to Croft, W. and Cruse, D., metaphor involves an interaction between two domains construed from two regions of purport, and the content of the vehicle domain is an ingredient of the construed target through processes of correspondence and blending. [6, p. 193] Broadly speaking, metaphor is a mechanism of speech. It is reflected in the way of using words of a certain class of objects or phenomena in order to define or identify the objects belonging to another class, or identify the other class, which has similarities with the default class in certain relationships.

Ex: "Tổ quốc ta như một con tàu

Mũi thuyền ta đó - Mũi Cà Mau".

(Xuân Diệu)

(Mũi Cà Mau: Ca Mau Nose = Ca Mau Cape)

Metaphor is a very popular way of meaning transfer in which the individual words or expressions are linked together due to their semantic similarities. It is formed by means of humanization, objectification, abstractionism, etc. It is used to enhance the expressiveness of the speech.

So, what is the cognitive metaphor mechanism of the perception verbs like?

\section{The Cognitive Metaphor Mechanism of the Perception Verbs}

Being a part of a linguistic system of a particular language the verb conveys national peculiarities of the conceptual system of its native speakers as well as the way a speaker visually perceives the environment. [3, p. 3] Based on meaning features, similarities, or similar elements in the same meaning category as well as the meaning proximity within each period of cognition or within the meaning group, these perception verbs can convey cognitive metaphors, which are distinctive, special, and diverse. These cognitive metaphor meanings enrich the semantic elements for the perception verbs.

For example, the verb thấy (see) is a verb belonging to the third period of the cognition process - the cognition result's output phase. This verb is used to express experiences. Due to those two reasons, this verb has some meaning features that are relatively close to those of the verb biêt (know). Therefore, we have a cognitive metaphor: thấy là đã biết (seeing is knowing).

Ex: Nhưng qua cô gái ấy, tôi thấy yêu được ai quả là một điều vô cùng hạnh phúc. But looking at her, I knew that being love must be extremely joyous.

\section{Cognitive Metaphors of the Vietnamese Perception Verbs}

\subsection{Cognitive Metaphors of the Verb Nhìn}

\section{-Nhin is watching}

Ex: Nhìn họ nói chuyện với Tây, với Tàu, với Nhật mà khoái. [15] It was satisfying to watch them speaking to Europeans, Chinese and Japanese. [16]

-Nhin is judging

Ex: Đó là nhược điểm chính của hắn; còn nhìn chung thì hắn rất được việc. [1] That is his main fault, but on the whole he's a good worker. [2]

-Nhin is facing

Ex: Nhìn mặt nhau suốt ngày ở phòng làm việc. [1] We faced each other at work in the office. [2]

-Nhin is longing to a certain direction

Ex: Cái điếm nhỏ trống hoang, tường xây bị lở từng mảng lớn, cửa điếm nhìn về phía bãi sông. [15] From its doorway, where they sat, they could see down to the riverbank. [16]

-Nhin is accepting

Ex: Có người không lấy chồng cho thỏa nghiệp, có người như đào Hồng có con rồi, vì mê hát, vì chiến tranh mà gởi con cho người ta, đến nước nó không thèm nhìn mình nữa. [15] She had remained true to her vow, and remained single for the sake of her art, even though finally her own son had rejected her because of her insistence on following her talent. [16]

Table 1. Cognitive metaphors of the verb nhin.

\begin{tabular}{|c|c|c|c|}
\hline Verb & Metaphor meanings & Units with metaphor & Percentage \\
\hline \multirow{5}{*}{ nhìn } & \multirow{5}{*}{$\begin{array}{l}\text { watching } \\
\text { judging } \\
\text { facing } \\
\text { longing to a certain } \\
\text { direction } \\
\text { accepting }\end{array}$} & 17 & $42.50 \%$ \\
\hline & & 10 & $25.00 \%$ \\
\hline & & 4 & $10.00 \%$ \\
\hline & & 5 & $12.50 \%$ \\
\hline & & 4 & $10.00 \%$ \\
\hline Total & & 40 & $100.00 \%$ \\
\hline
\end{tabular}




\subsection{Cognitive Metaphors of the Verb Thấy}

\section{-Thấy is thinking}

Ex: Ư', cô cũng thấy nên để má con toàn quyền! [15] I think we should give your mother complete authority here. [16]

\section{-Thấy is finding}

Ex: Nhưng dạo này Duyên bỗng thấy mình hay soi gương. [15] But during these days, Duyen suddenly found herself looking in the mirror. [16]

-Thấy is hearing

Ex: Từ khi sống bên nhau, lần đầu tiên, Ngoan thấy Mì to tiếng. [15] It was the first time since they had lived together that Ngoan had heard Mi raise her voice. [16]

\section{-Thấy is understanding}

Ex: Các ông thấy đấy, cảnh sống mà tôi vừa kể khiến chúng tôi không còn thích giao du với bất cứ ai cùng trang lứa và địa vị. [1] You can understand that, living the life which I have described, we were little likely to see anyone of our own age and position. [2]

\section{-Thấy is noticing}

Ex: Mình có thấy cách chi tiêu của hắn không? [15] Have you noticed the ways he spends money? [16]

-Thấy is watching

Ex: Tôi lặng nghe Muôn hát, thấy giọt nước mắt lăn trên gò má của cô. [15] While she sang I listened in silence, watching the tears spill down her cheeks. [16]

-Thấy is catching

Ex: Thấy tôi nhìn bàn tay, Mi bỏ xuống cười xòa. [15] Catching me looking down at that hand, she dropped it, and smiled apologetically. [16]

-Tháy is meeting

Ex: Tôi chưa thấy cô nào được như vậy. [15] I've never met a woman like that. [16]

\section{-Thấy is knowing}

Ex: Nhưng qua cô gái ấy, tôi thấy yêu được ai quả là một điều vô cùng hạnh phúc. [15] But looking at her, I knew that being love must be extremely joyous. [16]

-Thấy is observing

Ex: Trên dái tai hắn ông có thấy hai lỗ đeo hoa tai không? [1] Have you ever observed that his ears are pierced for earrings? [2]

\section{-Thấy is perceiving}

Ex: Tôi thấy mọi cái đều ổn. [1] I perceive that all is as it should be. [2]

\section{-Thấy is realizing}

Ex: Nhớ lại cái ngày mới vào đây, lấy xe đạp đạp vung các nơi, ông thấy mình đã thành ông lão rồi. [15] Remembering his early days in the city, when he would go everywhere on his bicycle, he realized how old he had gotten. [16]

\section{-Thấy is having}

Ex: Không thấy kinh nó lại giúp mình đỡ phiền hà. [15] Not having our periods actually simplified things for us. [16]

-Thấy is being impressed

Ex: Tôi thấy trong ít phút qua mà má như đã trải thêm hàng mấy năm trời, lưng còng thêm xuống. [15] I had the impression that the last few minutes had aged her many years; she seemd even more bent over now. [16]

-Thấy is agreeing

Ex: Đến thế mới thấy giỏi ngoại ngữ tức là giỏi nhất. [15] To that extent, one would have to agree that the best qualified were those who were good at foreign languages. [16]

-Thấy is witnessing

Ex: Lần đầu tiên tôi thấy một vẻ buồn đàn ông. [15] This was the first time I had ever witnessed such sadness in a man. [16]

\section{-Thấy is imagining}

Ex: Vâng, các ông thấy đó, thật là khó mà trở lại làm một công việc nặng nhọc để có lương 2 bảng một tuần. [1] Well, you can imagine how hard it was to settle down to arduous work at 2 pounds a week. [2]

-Thấy is distinguishing

Ex: Tôi thấy rõ dấu của một bàn chân còn ướt trên bờ cửa sổ. [1] I could distinguish the outline of an instep where the wet foot had been placed in. [2]

Table 2. Cognitive metaphors of the verb thấy.

\begin{tabular}{llll}
\hline Verb & Metaphor meanings & Units with metaphor & Percentage \\
\hline \multirow{4}{*}{ thinking } & 19 & $10.80 \%$ \\
& finding & 56 & $31.82 \%$ \\
& hearing & 15 & $8.52 \%$ \\
& understanding & 5 & $2.84 \%$ \\
& noticing & 20 & $11.36 \%$ \\
& watching & 6 & $3.41 \%$ \\
& catching & 10 & $5.68 \%$ \\
& meeting & 3 & $1.70 \%$ \\
thấy & knowing & 14 & $7.95 \%$ \\
& observing & 8 & $4.55 \%$ \\
& perceiving & 4 & $2.27 \%$ \\
& realizing & 10 & $5.68 \%$ \\
& having & 1 & $0.57 \%$ \\
& being impressed & 1 & $0.57 \%$ \\
& agreeing & 1 & $0.57 \%$ \\
& witnessing & 1 & $0.57 \%$ \\
imagining & 1 & $0.57 \%$ \\
Total & distinguishing & 1 & $0.57 \%$ \\
\hline
\end{tabular}

\subsection{Cognitive Metaphors of the Verb Nghe}

-Nghe is obeying

Ex: Ông tôi không nghe. [1] My grandfather refused to obey. [2]

-Nghe is understanding

Ex: Đấy, thế đấy, chú nghe rõ chưa? [15] Do you understand? [16]

-Nghe is consulting

Ex: Tôi đi thẳng từ Praha đến đây để $n g h e$ lời khuyên của các ông. [1] I have come incognito from Prague for the purpose of consulting you. [2]

-Nghe is knowing

Ex: Nghe nói, hồi đó, nhà ông giàu có khét tiếng xứ Bạc Liêu. [15] It was well known that he came from a very rich family in Bac Lieu. [16]

-Nghe is distinguishing

Ex: Mà vui thật, vui ra phết, bà $n g h e$ rõ tiếng từng con một, mỗi con một giọng, mỗi kiểu gáy. [15] And lift her spirit it did, it was downright humorous, she could distinguish 
clearly the sound of each cock, each one had its own distinct voice, its own way of crowing. [16]

-Nghe is feeling

Ex: Tôi bất chợt nghe lạnh suốt lưng. [15] I felt suddenly chilled to the spine. [16]

-Nghe is catching

Ex: Đây chính là từ mà người hấp hối thốt ra, nhưng anh con trai chỉ kịp nghe có hai âm tiết cuối cùng. [1] That was the word the man uttered, and of which his son only caught the last two syllables. [2]

-Nghe is finding

Ex: Thầy chưa nghe nói gỗ đá thành Phật bao giờ. [15] I've never found a stone or a piece of wood that could become a Buddha. [16]

-Nghe is thinking

Ex: Ông cũng nghe như thế ư? [15] You think so, too? [16] -Nghe is checking

Ex: Sáng hôm sau, nhà lại vắng như mọi hôm, bà lão Tứ nghe ngóng xung quanh im ả, rồi lần lần vào bếp. [15] But the next morning, when everyone was out of the house again, Mrs. Tu checked to make sure no one was around, and then groped her way back to the kitchen. [16]

-Nghe is sounding

Ex: Nghe mù mờ mà hấp dẫn quá. [15] It sounded so vague and yet so attractive. [16]

Table 3. Cognitive metaphors of the verb nghe.

\begin{tabular}{llll}
\hline Verb & Metaphor meanings & Units with metaphor & Percentage \\
\hline \multirow{4}{*}{ obeying } & 11 & $30.55 \%$ \\
& understanding & 2 & $5.56 \%$ \\
& consulting & 2 & $5.56 \%$ \\
& knowing & 2 & $5.56 \%$ \\
& distinguishing & 2 & $5.56 \%$ \\
& feeling & 4 & $11.10 \%$ \\
& catching & 3 & $8.33 \%$ \\
& finding & 2 & $5.56 \%$ \\
& thinking & 2 & $5.56 \%$ \\
& checking & 1 & $2.78 \%$ \\
& sounding & 5 & $13.88 \%$ \\
\hline
\end{tabular}

\subsection{Cognitive Metaphors of the Verb Nghe Thấy}

-Nghe thấy is receiving

Ex: Thành tích này của ông chúng tôi đã từ khắp nơi nghe thấy. [15] This account of you we have from all quarters received. [16]

-Nghe thấy is seeing

Ex: Về phần cô ta, tôi không nghe thấy gì. [1] Of her, I could see nothing. [2]

-Nghe thấy is catching

Ex: Cha tôi có lắp bắp mấy tiếng không rõ, tôi chỉ nghe thấy một từ hình như là "A rat". [1] He mumbled a few words, but I could only catch some allusion to a rat. [2]
Table 4. Cognitive metaphors of the verb nghe thấy.

\begin{tabular}{llll}
\hline Verb & Metaphor meanings & Units with metaphor & Percentage \\
\hline \multirow{3}{*}{ nghe thấy } & receiving & 3 & $60.00 \%$ \\
& seeing & 1 & $20.00 \%$ \\
\multirow{2}{*}{ Total } & catching & 1 & $20.00 \%$ \\
\hline
\end{tabular}

\subsection{Cognitive Metaphors of the Verb Ngüi}

-Ngüi is taking

Ex: Kẻ ăn trộm gà, người hàng xóm đơn độc, suốt ba trăm sáu mươi lăm ngày qua vẫn ngồi ủ rũ ngó qua, âm thầm ngưi mùi hương khói nhà bà. [15] The rooster thief, her solitary neighbor, sat disconsolate throughout the three hundred and sixty-five days and gazed across, silently taking in the fragrance of the incense in her house. [16]

Table 5. Cognitive metaphors of the verb ngüi.

\begin{tabular}{llll}
\hline Verb & Metaphor meanings & Units with metaphor & Percentage \\
\hline ngửi & taking & 2 & $100.00 \%$ \\
Total & & 2 & $100.00 \%$ \\
\hline
\end{tabular}

\subsection{Cognitive Metaphors of the Verb Ngửi Thấy}

-Ngưi thấy is existing

Ex: Bầu trời xanh nhạt, những đám mây trong, trôi êm ả từ tây sang đông, mặt trời chói lọi, có thể ngưi thấy mùi nhựa sống trong không khí. [15] It was an ideal spring day, a light blue sky, flecked with little fleecy white clouds drifting across from west to east. The sun was shining very brightly, and yet there was an exhilarating nip in the air, which set an edge to a man's energy. [16]

Table 6. Cognitive metaphors of the verb ngưi thấy.

\begin{tabular}{llll}
\hline Verb & Metaphor meanings & Units with metaphor & Percentage \\
\hline ngửi thấy & existing & 1 & $100.00 \%$ \\
Total & & 1 & $100.00 \%$ \\
\hline
\end{tabular}

\subsection{Cognitive Metaphors of the Verb Nếm}

-Nếm is experiencing

Ex: Nhưng chúng ta sẽ còn phải nếm đủ mùi khủng khiếp chừng nào đêm nay còn chưa trôi qua. [15] But we shall have horrors enough before the night is over. [16]

Table 7. Cognitive metaphors of the verb nếm.

\begin{tabular}{llll}
\hline Verb & Metaphor meanings & Units with metaphor & Percentage \\
\hline nếm & experiencing & 1 & $100.00 \%$ \\
Total & & 1 & $100.00 \%$ \\
\hline
\end{tabular}

\subsection{Cognitive Metaphors of the Verb Sò̀}

\section{-Sò̀ is reaching}

Ex: Tỉnh dậy, sờ lên mặt chỉ thấy máu. [15] When I woke up and reached up to wipe my face, I felt that it was covered in blood. [16]

-Sò̀ is focusing attention

Ex: Tôi tự sờ lên đầu mình để kiểm tra, không còn nghi ngờ gì nữa, cú đánh như vậy chỉ có thể thực hiện từ phía sau lưng nạn nhân. [1] I marked the spot upon my own head. 
Clearly such a blow must have been struck from behind. [2] -Sờ is feeling

Ex: Tôi bò quẩn mãi, chỉ sờ mó thôi chứ mắt có thấy gì nữa đâu! [1] I crawled all over, feeling the ground, unable to see anything. [2]

Table 8. Cognitive metaphors of the verb sò:

\begin{tabular}{llll}
\hline Verb & Metaphor meanings & Units with metaphor & Percentage \\
\hline \multirow{3}{*}{ sờ } & reaching & 1 & $20.00 \%$ \\
& focusing attention & 1 & $20.00 \%$ \\
\multirow{2}{*}{ Total } & feeling & 3 & $60.00 \%$ \\
\hline
\end{tabular}

\section{Modes of the Cognitive Metaphors of the Perception Verbs}

\subsection{Due to the Dominance of the Cognitive Object}

These are the metaphors formed owing to the dominance of the semantic requirements and properties of the cognitive object. For example:

Ex: Mi nhìn tôi ăn chăm chú nhưng tôi biết rõ cô không nhìn thấy gì hết. [15]

In this example, the cognitive object of nhin (look) is tôi $\breve{a n}$ (I eat). This cognitive object is a process. Therefore, the verb nhin in this example convey the metaphor meaning of theo dõ (watching). As a result, we have the English version of this sentence: Mi watched me eating attentively, but I knew clearly that she was not seeing anything. [16]

Table 9. Statistics of cognitive metaphors formed due to the dominance of the cognitive object.

\begin{tabular}{|c|c|c|c|}
\hline Verb & Metaphor meanings & $\begin{array}{l}\text { Units with } \\
\text { metaphor }\end{array}$ & Percentage \\
\hline \multirow{4}{*}{ nhìn } & watching & 17 & $6.03 \%$ \\
\hline & judging & 10 & $3.55 \%$ \\
\hline & facing & 4 & $1.40 \%$ \\
\hline & longing to a certain direction & 5 & $1.75 \%$ \\
\hline \multirow{6}{*}{ thấy } & hearing & 15 & $5.32 \%$ \\
\hline & watching & 6 & $2.13 \%$ \\
\hline & catching & 10 & $3.55 \%$ \\
\hline & observing & 8 & $2.84 \%$ \\
\hline & having & 1 & $0.35 \%$ \\
\hline & witnessing & 1 & $0.35 \%$ \\
\hline nghe & sounding & 5 & $1.75 \%$ \\
\hline ngửi thấy & existing & 1 & $0.35 \%$ \\
\hline sờ & reaching & 1 & $0.35 \%$ \\
\hline Total & & 282 & $30.07 \%$ \\
\hline
\end{tabular}

\subsection{Due to the Dominance of the Cognitive Perceiver}

These are the metaphors formed owing to the dominance of the semantic requirements and properties of the cognitive perceiver. For example:

Ex: Ư', cô cũng thấy nên để má con toàn quyền! [15]

In this example, we can see that the verb thấy (see) is used to describe the thinking of the cognitive perceiver cô (the aunt). Therefore, we have the corresponding English translation of the sentence is: I think we should give your mother complete authority here. [16]
Table 10. Statistics of cognitive metaphors formed due to the dominance of the cognitive perceiver.

\begin{tabular}{|c|c|c|c|}
\hline Verb & Metaphor meanings & Units with metaphor & Percentage \\
\hline nhìn & accepting & 4 & $1.40 \%$ \\
\hline \multirow{11}{*}{ thấy } & thinking & 19 & $6.74 \%$ \\
\hline & finding & 56 & $19.86 \%$ \\
\hline & understanding & 5 & $1.75 \%$ \\
\hline & noticing & 20 & $7.09 \%$ \\
\hline & meeting & 3 & $1.05 \%$ \\
\hline & knowing & 14 & $4.96 \%$ \\
\hline & perceiving & 4 & $1.40 \%$ \\
\hline & realizing & 10 & $3.55 \%$ \\
\hline & being impressed & 1 & $0.35 \%$ \\
\hline & agreeing & 1 & $0.35 \%$ \\
\hline & imagining & 1 & $0.35 \%$ \\
\hline \multirow{11}{*}{ nghe } & distinguishing & 1 & $0.35 \%$ \\
\hline & obeying & 11 & $3.90 \%$ \\
\hline & understanding & 2 & $0.70 \%$ \\
\hline & consulting & 2 & $0.70 \%$ \\
\hline & knowing & 2 & $0.70 \%$ \\
\hline & distinguishing & 2 & $0.70 \%$ \\
\hline & feeling & 4 & $1.40 \%$ \\
\hline & catching & 3 & $1.05 \%$ \\
\hline & finding & 2 & $0.70 \%$ \\
\hline & thinking & 2 & $0.70 \%$ \\
\hline & checking & 1 & $0.35 \%$ \\
\hline \multirow{3}{*}{ nghe thấy } & receiving & 3 & $1.05 \%$ \\
\hline & seeing & 1 & $0.35 \%$ \\
\hline & catching & 1 & $0.35 \%$ \\
\hline ngửi & taking & 2 & $0.70 \%$ \\
\hline nếm & experiencing & 1 & $0.35 \%$ \\
\hline \multirow{2}{*}{ sờ } & focusing attention & 1 & $0.35 \%$ \\
\hline & feeling & 3 & $1.05 \%$ \\
\hline Total & & 282 & $69.93 \%$ \\
\hline
\end{tabular}

\subsection{Due to Being in the Same Cognition Phase}

The percentage of the cognitive metaphors formed due to being in the same cognition phase is extremely high. For cognitive metaphors in Vietnamese, the percentage is $93.61 \%$, and that in English is $98.47 \%$.

The cognitive metaphors formed due to not being in the same cognition phase account for only a small proportion shown in the following table.

Table 11. Statistics of cognitive metaphors formed due to not being in the same cognition phase.

\begin{tabular}{llll}
\hline Verb & Metaphor meanings & Units with metaphor & Percentage \\
\hline nhìn & accepting & 4 & $1.42 \%$ \\
& watching & 6 & $2.13 \%$ \\
thấy & observing & 8 & $2.84 \%$ \\
Total & & 282 & $6.39 \%$ \\
see & quan sát & 12 & $1.53 \%$ \\
Total & & 785 & $1.53 \%$ \\
\hline
\end{tabular}

\subsection{Due to Cognitive Spaces Switching}

These are the metaphors formed owing to cognitive spaces switching. They are the switching from the reality space to the assuming space (Ex: nhìn is judging, nhìn is accepting, etc.), from the assuming space to the cognition space (Ex: thấy is thinking, thấy is understanding, etc.), from the reality space to the experience space (Ex: thấy is knowing, thấy is realizing, etc.), and more. 


\subsection{Due to Cognitive Results Conversion}

These are the metaphors formed owing to the conversion of the cognitive results of other verbs into the perception verbs. For example, we have the metaphors such as thấy is finding, thấy is realizing, thấy is perceiving, etc.

\subsection{Due to Perception Organs Conversion}

These are the metaphors formed owing to the conversion of the perception organs. In Vietnamese, the verb thấy of the visual perception and the verb nghe of the hearing perception can be used to convey the cognitive results of all the senses, not just the visual and the hearing only.

\section{Conclusion}

The survey results have shown us that the cognitive meanings of the perception verbs are extremely diverse, various, and special. Among them, the meanings with cognitive metaphors account for a big proportion.

The polysemy, sophistication, and subtlety of the perception verbs have enriched the language. However, they meanwhile, cause a huge obstacle to language learners and language workers. Therefore, it is necessary to pay utmost attention to the identification of the exact meanings in each certain linguistic unit when teaching or handling with languages.

Further studies of these verbs as well as their contrastive research within multi-languages are also very essential work.

Finally, this research has made a very important sense not only in linguistic study but also in language teaching, learning, in translating and interpreting, and many other activities in relation with languages.

\section{References}

[1] Arthur, C. D. (2009) Những cuộc phiêu lưu của Sherlock Holmes. Văn học.
[2] Arthur, C. D. (1999) The adventures of Sherlock Holmes. The Project Gutenberg.

[3] Babina, L. V. and Budantseva, N. A. (2015) The basic level of taxonomy of the concept «visual perception» (the case study of English and French verbs). Сетевой научно-практический журнал, No. 2, 44-49. Tambov, Russia.

[4] Bara, B. G. (2010) Cognitive Pragmatics - The Mental Processes of Communication. MIT Press.

[5] Brdar, M., Gries, S. T. and Fuchs, M. Z. (2011) Cognitive Linguistics - Convergence and Expansion. John Benjamins Publishing Company.

[6] Croft, W. and Cruse, D. A. (2004) Cognitive Linguistics. Cambridge University Press.

[7] Evans, V. and Green, M. (2006) Cognitive Linguistics - An Introduction. Edinburgh University Press.

[8] Fauconnier, G. (1995) Mental Spaces, 2nd ed. Cambridge University Press.

[9] Fillmore, C. J. (1982) Frame Semantics. Towards a descriptive framework for spatial deixis. Speech, place and action. New York.

[10] Geeraerts, D. (2006) Cognitive Linguistics: Basic Readings. Mouton de Gruyter.

[11] Geeraerts, D. and Cuyckens, H. (2007) The Oxford Handbook of Cognitive Linguistics. Oxford University Press.

[12] Kristiansen, G. (2006) Cognitive Linguistics: Current Applications and Future Perspectives, Mouton de Gruyter.

[13] Robinson, P. and Ellis, N. C. (2008) Handbook of Cognitive Linguistics and Second Language Acquisition. Routledge.

[14] Rojo, A. and Valenzuela, J. (2005) Verbs of sensory perception: An English - Spanish comparison, John Benjamins.

[15] Wayne, K. and Thái, H. A. (2004) Tình yêu sau chiến tranh. Hội Nhà văn.

[16] Wayne, K. and Thai, H. A. (2003) Love after war. Curbstone Press. 